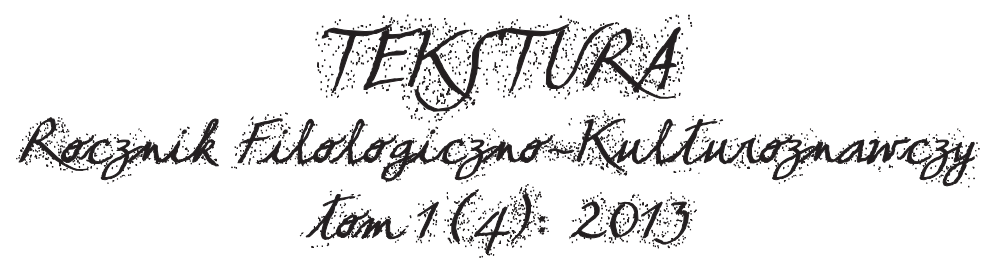

Eukasz Grajewski

Koniec SENSU KOŃCEM ŚWIATA?
Poetyckie POSZUKIWANIA JERZEGo ŻUŁAWSKIEGo

W poetyckiej twórczości Jerzego Żuławskiego tytułowy koniec świata poza wyjątkami nie przybiera postaci globalnej katastrofy, powszechnej śmierci milionów ludzi czy siejących postrach jeźdźców apokalipsy. Nie o to tutaj chodzi. Koniec świata ma tu wymiar jednostkowy, pseudonimuje świadomość rozpadu koherencji dotychczasowych wyobrażeń rzeczywistości, co prowadzi do prób rekonstruowania rozrzuconych elementów układanki. Proces ten nieuchronnie prowadzi do permanentnej kontestacji w duchu dekadentyzmu przełomu XIX i XX w. Negacja jest w tej twórczości wynikiem refleksji aposteriorycznej, podmiot liryczny staje się bowiem podmiotem doświadczającym. Całość poezji Jerzego Żuławskiego możemy ująć jako wędrówkę w poszukiwaniu straconego sensu.

Tak w kilku zdaniach moglibyśmy przedstawić liryczną twórczość autora Na srebrnym globie. Niewiele to jednak mówi o jej podstawach filozoficznych i drodze, którą przebył od pierwszych aktywistycznych utworów do rozczarowania i postulatów kontemplacji oraz wyciszenia. Od świata początku do świata końca. Dlatego też w dużym skrócie i z konieczności fragmentarycznie spróbuję dociec, dlaczego Żuławski unicestwił świat w swoich wierszach.

\title{
Świat cierpienia
}

Doświadczeniem łączącym większość utworów lirycznych autora Stancy o pieśni jest cierpienie, od którego nie ma ucieczki, a którego źródłem jest wiecznie niezaspokojone pragnienie skutkujące m.in. immanentnie istnieją- 
cym w człowieku złem lub też wysoce rozwinięta samoświadomość. Egzystencja ludzka zostaje sprowadzona do form radzenia sobie z doznawaniem nie tylko fizycznego bólu, jak w wierszu Zły gad, gdzie animizowane cierpienie „ze sykiem wyciąga szyję i żywe ciało swej ofiary rwie”.

Absolutyzację cierpienia pokazuje utwór Żuławskiego trawestujący renesansową koncepcję Giovanniego Pico della Mirandoli, według której człowiek niczym na drabinie bytów może wznosić się w samodoskonaleniu lub upadlać jak istoty coraz to nikczemniejsze. W ujęciu polskiego poety temu wznoszeniu paradoksalnie towarzyszy cierpienie, którego jest tym więcej, im doskonalszy staje się człowiek. Zresztą nie tylko istota ludzka podlega temu prawu, podmiot liryczny Cierpienia pyta bowiem:

Jakichż więc cierpień nosisz w sobie morze,

Ty, coś z wszechistot snadź najwyższy, Boże?!²

Pragnienie oraz świadomość wyznaczają zatem horyzonty dekadentyzmu poety.

\section{Filozoficzne inspiracje - Blaise Pascal}

Żuławski nie był filozofem par excellence ${ }^{3}$, toteż jego twórczość poetycka nie stanowi artystycznego quasi-systemu filozoficznego, możemy wskazać jednakże choćby pokrótce i z konieczności częściowo źródła inspiracji poety.

Niemożność zaspokojenia pragnień i nieustająca pożądliwość człowieka są $\mathrm{z}$ ducha pascalowskie - to m.in. na tę cechę ludzkiej natury zwracał uwagę Blaise Pascal. Według niego człowiek, zaspokoiwszy swoje pragnienia, stwarza sobie nowe, pragnąc coraz więcej. Pożądliwość ludzka nie zna granic, a jej zaspokojenie w żadnej mierze nie może stanowić drogi do szczęścia. Według Pascala to dążenie do celu jest atrakcyjne, nie zaś jego osiąganie: „Tak upływa całe życie. Szukamy spokoju, zwalczając jakieś przeszkody; kiedy je przezwyciężymy, spokój staje się nie do zniesienia. Albo się myśli o tych nie-

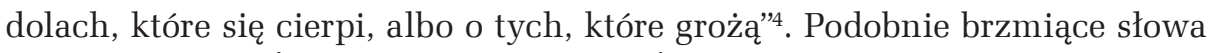
odnajdziemy i u Żuławskiego w wierszu Życie:

\footnotetext{
1 J. Żuławski, Zły gad, [w:] tenże, Poezje, t. 1-4, Lwów 1908, s. 191.

2 Tenże, Cierpienie, [w:] tenże, dz. cyt., s. 217.

${ }^{3}$ Choć - co warto zaznaczyć - miał wykształcenie filozoficzne.

${ }^{4}$ B. Pascal, Myśli, przeł. T. Żeleński-Boy, Warszawa 2012, s. 89.
} 
I nie wiem, dlaczego

taką krzywdę-ś mi, Życie, zrobiło, że wszystko

dałoś, czegom zapragnął...? Snadź by mnie przekonać,

żem źle pragnął i że jest wszelakie pragnienie

samo w sobie boleścią - a spełnienie pragnień

najżywszych nieprzerwanem pasmem rozczarowań,

chociażby rzeczywistość przeszła sny najśmielsze... ${ }^{5}$.

Gdy przyjrzeć się poezji Żuławskiego, są widoczne - zamierzone lub nie - także inne związki z filozofią Pascala. Wystarczy wskazać na krytykę racjonalizmu, doczesności czy miłości. Obaj poświęcili się poszukiwaniu, ich twórczość ma charakter pragmatyczny, gdyż jej celem było rozmaicie realizowane przywracanie sensu.

Pascal w swoim głównym dziele Myśli zawarł krytykę wiedzy i rozumu, który nie jest w stanie pojąć istoty Boga i rzeczywistości. Filozofowi nie wystarczyła sama znajomość faktów pozbawiona ich rozumienia. Efektem takiej postawy był słynny „zakład Pascala” oparty nie na pewności, lecz na wywiedzionej z nauk matematycznych teorii prawdopodobieństwa ${ }^{6}$. Wiedza stała się w tym ujęciu „próżnością” i „,szaleństwem”.

Nie tak radykalny w swej wymowie był Żuławski, lecz i on wyraził krytykę mądrości oraz racjonalizmu. Przykładem tego może być wiersz Palimpsest z tomu Dolce stil nuovo, gdzie znaczenie tytułu zostaje odniesione do bytu, a prawda jest ukryta gdzieś pod „stu linij natłokiem”. Warto zauważyć, że ten wiersz jest również krytyką kultury czy też takiego modelu filozofii, który zamiast dążyć do poznania prawdy, przeniknięcia istoty bytu, dodaje kolejne „linie” do palimpsestu, gubiąc w ten sposób przedmiot pierwotnego zainteresowania.

Żuławski podejmuje także historię Fausta w niewielkim dramacie poetyckim Faust i Mefistofeles oraz wykorzystuje motywy biblijne jak choćby w poemacie Z kaznodziejskiej księgi Salomona. Oba utwory stanowią m.in. krytykę wiedzy nieprzynoszącej szczęścia, mającej wymiar jedynie autoteliczny i niegwarantującej dostatecznego rozpoznania świata oraz istoty Boga.

${ }^{5}$ J. Żuławski, Życie, [w:] tenże, dz. cyt., s. 262.

6 Zob. B. Pascal, dz. cyt., s. 177-184.

${ }^{7}$ J. Żuławski, Palimpsest, [w:] tenże, dz. cyt., s. 220. 


\section{Filozoficzne inspiracje - Artur Schopenhauer}

O ile jednak związek poezji Żuławskiego z filozofią Pascala jest stosunkowo powierzchowny, o tyle znacznie więcej łączyło poetę z myślą bardziej współczesnego mu filozofa - Artura Schopenhauera. Liryka autora Na srebrnym globie nie stanowi, co prawda, artystycznej egzemplifikacji tez filozofa, jednakże bez trudu odnajdziemy w niej zbieżności, a nawet bezpośrednie inspiracje i aluzje.

Jeśli przyjmiemy założenie, że poezja Żuławskiego tworzy pewien mniej lub bardziej spójny zbiór sądów o świecie, to będziemy mogli nazwać ją metafizyką uzasadnioną empirycznie. Powiedzieliśmy już o podmiocie lirycznym tych utworów, że jest on podmiotem doświadczającym. Empiria jest tu drogą poznania i źródłem wiedzy o sobie samym, a co za tym idzie - o człowieku oraz świecie w ogóle. W autotematycznej rozmowie podmiotu lirycznego z własną muzą w wierszu Moja piosnka na zadane jej pytania, czemu „duma o grobie” i nie śmieje się, tak jak tego oczekują od niej ludzie, ta odpowiada: „Jam młoda, lecz widziałam wiele!”, w całym zaś utworze zostały nagromadzone czasowniki „,widziałam” i „zobaczyłam”.

Imperatyw aposterioryczności sądów jest tu czymś, co już na dużym stopniu ogólności spojrzenia łączy pisarską praktykę Żuławskiego z myślą Schopenhauera. Filozof ten odżegnywał się przecież od wszelkiego aprioryzmu, stojąc tym samym w opozycji wobec metafizyki Kanta i wszelkiej spekulatywnej filozofii tworzącej jedynie hipostazy oderwane od doświadczenia9 ${ }^{9}$.

Zbieżność najistotniejszą stanowi jednakże Schopenhauerowska teza o świecie jako zbiorze przedmiotów, które stanowią jednostkowe uprzedmiotowienia woli ${ }^{10}$. Teza ta i płynące $\mathrm{z}$ niej konsekwencje wraz z nieustającym zainteresowaniem filozofią indyjską przyczyniły się do rozwoju nastrojów dekadenckich XIX wieku' ${ }^{11}$. Nieobojętny pozostał na nie również Żuławski, czemu dał wyraz w swoim poemacie Lotos powstałym w latach 1894-1898.

${ }^{8}$ J. Żuławski, Moja piosnka, [w:] tenże, dz. cyt., s. 155.

9 Zob. J. Garewicz, Schopenhauer, Warszawa 1970.

${ }^{10}$ Nie rozwijam tu szczegółowo filozofii Schopenhauera, sądząc, że jej podstawy są dostatecznie znane. Zainteresowanych odsyłam do książki Garewicza (zob. przyp. 5).

${ }^{11}$ Oczywiście nie są to jedyne czynniki, które miały wpływ na ekspansję dekadentyzmu w sztuce i myśli schyłku wieku XIX. Zob. R. Zimand, „Dekadentyzm” warszawski, Warszawa 1964. 
Odnajdziemy tam przede wszystkim inspiracje filozofią indyjską, ale i wpływ Schopenhauera:

Tak mędrcy prawią, że tej duszy treścią wieczne pragnienie; pragnienia wynikiem życie, a życie jedną jest boleścią!

$[\ldots]$ trzeba kamieniem stać się, zabić wolę, a wtedy dusza w nicość się rozpływa, bo z bólem życie, z wolą giną bole!.... ${ }^{12}$.

W wersach dalszych, mówiących o głosie pieśni jako o głosie Boga, który tworzy, możemy doszukać się związku z Schopenhauerowską koncepcją geniusza jako przewodnika duchowego ludzkości, objawiającego jej istotę rzeczywistości. W ujęciu Żuławskiego pieśniarz przeobraża świat lub z własnej myśli ,jestestwa nowe wyplata"13. Pokrewieństwo z modelem geniusza Schopenhauera jest tu oczywiście niebezpośrednie i nieoczywiste, jednak jest widoczna zbieżność myśli o roli artysty jako kreatorze oraz przewodniku, kimś, czyją domeną jest elitarna wiedza. Podobne są tu zresztą konsekwencje - zarówno Schopenhauerowski geniusz, jak i pieśniarz Żuławskiego cierpią, nawet bardziej niż inni ludzie (vide wspominany utwór Cierpienie!), wskutek szczególnego stężenia namiętności, wiecznie głodnej woli ${ }^{14}$. Czytamy w Lotosie:

Nieświadomość cięży

nieznośnie duszy, która płacze w mroku;

lecz kto zagadkę ujmie i zwycięży

i wydrze prawdę odwieczną wszechbytu

$[\ldots]$

stokroć nędzniejszy, niż ten, co na zorzę

patrząc daleką, z tęsknoty umiera! $!^{15}$

Jedynym rozwiązaniem jest rezygnacja z pragnień, przełamanie i zaprzeczenie żarłocznej woli. Według Schopenhauera umożliwia to albo asceza,

12 J. Żuławski, Lotos, [w:] tenże, dz. cyt., s. 138-139.

13 Tamże, s. 143.

14 Zob. J. Garewicz, dz. cyt., s. 83-85.

15 J. Żuławski, Lotos, s. 186. 
albo graniczne doznanie wielu cierpień, gdy - jak pisze Jan Tuczyński - „poznajemy cierpienie świata i własną istotę przez odczucie własnej masy nadmiernego bólu" ${ }^{\prime 6}$. Pierwszy wariant drogi ku nirwanie - ascetyczny - prezentuje tytułowy bohater utworu Żuławskiego Święty Szymon Słupnik. Poeta zdaje się tu pokazywać niemożność, a przynajmniej trudność, prawdziwej ascezy. Szymon Słupnik ponosi bowiem klęskę, jego motywami kierują pycha i gniew: pragnie on ujrzeć zagładę grzesznego miasta, prosi Boga o apokalipsę, czując przy tym swoją wyższość nad resztą ludzkości. Ostatecznie bohater daje się uwieść pokusom „tańczących półnagich kobiet” ${ }^{17}$, dopuszcza się nawet bluźnierstwa:

Lata strawiłem - głupiec! - na tym słupie -

Pan Bóg nie słyszał - marne lata, głupie!

Miasto wciąż stoi - pyszne! grzech się sroży...

Rozkosz szpik wyschły dreszczem mi przenika -

twe dłonie! usta!.. Precz! ja święty! boży --

Piersi twe... Ginę... Światło, woń, muzyka...

wołasz mnie - idę - w otchłań... ${ }^{18}$.

Szymon Słupnik, pomimo prób unieważnienia czasu i przestrzeni - stał on bowiem nieruchomo $\mathrm{w}$ jednym miejscu, a więc pomimo prób wyjścia poza zasadę przyczynowości, poniósł klęskę. Zresztą nawet przed ulegnięciem pokusom kobiet tkwił pod przemożnym wpływem woli, pożądając nadejścia apokalipsy, która uprawomocniłaby jego ascezę, nadała sens poświęceniu. Zamiast spełnienia i nagrody Szymon Słupnik czuł irytację oraz cierpienie. Jego postawa nie miała nic wspólnego z rezygnacją, bezwarunkowym wyrzeczeniem, które nie pożąda niczego w zamian. Nirwana nie była tu zatem możliwa.

Jak pokazuje Żuławski, nie każda asceza będzie prowadzić do zaprzeczenia woli. Redefiniuje on prawdziwą ascezę rozumianą w duchu Schopenhauera jako postawę bezwarunkowej rezygnacji, pozbawioną oczekiwania innej nagrody czy zadośćuczynienia niż mortyfikacji woli.

\footnotetext{
${ }^{16}$ J. Tuczyński, Schopenhauer a Młoda Polska, Gdańsk 1969, s. 57.

17 Warto zaznaczyć, że w myśli Schopenhauera kobiety są przykładem najpotężniej ugruntowanej ślepej woli do życia, posiadają one bowiem więcej instynktu gatunku niż mężczyzna. Zob. tamże, s. 46-48.

18 J. Żuławski, Święty Szymon Słupnik, [w:] tenże, dz. cyt., s. 141.
} 
Czy zatem druga droga - przez cierpienie - okaże się w poezji Żuławskiego skuteczniejsza? Poeta podjął bowiem biblijny motyw Hioba w utworze Z ksiąg Ijoba Cierpliwego. I tutaj jednakże osiągnięcie nirwany jest niemożliwe, zamiast tego Ijob złorzeczy, dopuszcza się bluźnierstw, obarczając Boga odpowiedzialnością za doznawane cierpienia. Porażki Ijoba oraz Szymona Słupnika pokazują trudność przełamania woli i zdają się potwierdzać tezę Schopenhauera o elitarności stanu nirwany.

Żarłoczność woli pokazują także inne utwory poetyckie Żuławskiego, warto jeszcze przywołać w tym miejscu choćby dwa z nich. Szczególnym pod tym względem jest wiersz Wrażeń!, w którym świadomość podmiotu lirycznego - werbalizowana w ponawianych skargach i żądaniach podniet stanowi dobrą reprezentację nieustającego stanu antynomii nieposkromionej woli i niemożności zaspokojenia pragnień. W konsekwencji istnienie ludzkie przynosi tu cierpienie i rozczarowanie, jest niepełne, przepołowione:

Ale martwić w pól-życiu i pól-świetle tylko, czuć, że jest gdzieś kraina wszechszczęścia świetlana, a pokrzepiać się ledwo marnych kropel kilką spadłych w duszę przypadkiem - o! raczej nirwana, raczej nie czuć, nie myśleć, przestać istnieć wcale, niż na Prometeusza zwolna konać skale!

Niech przeklęty mi będzie los ów, który stworzył w łaskawości niezmiernej potwora-człowieka, który w duszę mu żądzę dziką szczęścia włożył, marę gonić mu kazał, co wiecznie ucieka! ${ }^{19}$.

Alegorią człowieka, który pozostaje pod przemożnym wpływem woli, jest „Donkiszot” z wiersza Fragment. Żuławski zawarł tu komentarz do ponawianych przez bohatera wysiłków, tworząc uniwersalną refleksję o człowieku w ogóle, refleksję w duchu myśli Schopenhauera:

Jest moc w człowieku jakaś czy fatalność,

która mu powstać każe, choć upadnie,

i iść mu każe, chociaż rad by spocząć,

i wierzyć znowu w to wszystko, co wczoraj

złudą się jeno okazało marną,

19 Tenże, Wrażeń!, [w:] tenże, dz. cyt., s. 107-108. 
i chcieć znów tego, czego mu sto razy

życie już pragnąć zakazało ${ }^{20}$.

Pisząc o świecie jako woli, Schopenhauer pokazał sprzeczność dążenia wszystkich zindywidualizowanych przedmiotów: od martwego kamienia do posiadającego świadomość człowieka. Dwoje ludzi pożądających tego samego jest sobie wrogie, wygrywa zaś silniejszy. I to jest właśnie przyczyną istniejącego zła na świecie, zła, które stało się w myśli Schopenhauera czymś immanentnym, wpisanym w definicję rzeczywistości. To nie zło jest brakiem dobra, lecz dobro jest chwilowym brakiem zła powiada filozof. Każde szczęście ludzkie nosi w sobie zarodek zła, jest ono bowiem spełnieniem pragnień dokonywanym kosztem szczęścia innych ludzi. Suma rozkoszy doznawanej przez lwy pożerające antylopę jest nieskończenie mniejsza od bólu umierającego zwierzęcia. Te same prawa żądzą zatem szczęściem ludzkim i zwierzęcą rozkoszą. Pozytywną wartość nosi jedynie czyn bezinteresowny i spontaniczny, akt czystej litości.

Schopenhauerowska aksjologia znajduje swoje odbicie w wierszu Żuławskiego Tyżeś to, morze..., w którym szczęście ludzkie oddane morzu, aby tam było bezpieczne i czekało na swojego „posiadacza”, zmienia spokojną, lazurową wodę w „odmęt zorany bruzdami fal/ spieniony, ryczący, wściekły”21. Podmiot liryczny, widząc ten niemal apokaliptyczny żywioł, pyta:

Więc nawet w szczęściu

ludzkim jest tyle goryczy

i tyle zła,

że zdolne spienić morze i zamącić

do dna,

ogromne, bezbrzeżne morze....? ${ }^{22}$

W kontekście Schopenhauerowskiej aksjologii możemy interpretować również inny utwór Żuławskiego - Galateę, w którym ludzie niszczą ideał wykuty przez podmiot liryczny:

To jest pieśń ta? - To odgłos mordu i pożogi!

bratobójczych walk szczęki i krzyki rozpaczy! -

20 Tenże, Fragment, [w:] tenże, dz. cyt., s. 293.

21 Tenże, Tyżeś to, morze..., [w:] tenże, dz. cyt., s. 210.

22 Tamże, s. 212. 
Stójcie! - posąg mój pada! - stójcie! co to znaczy?!"3

Jak zatem widzimy, filozofia Schopenhauera znajduje swoje reminiscencje w poetyckiej twórczości Żuławskiego. Czasem są to oczywiście jedynie pewne podobieństwa myśli, zbieżności może nawet nie do końca uświadamiane przez poetę. Nie jest jednak istotne, czy Żuławski w momencie pisania tego lub innego utworu myślał bezpośrednio o Schopenhauerze. Zbieżność pozostaje zbieżnością.

Końcowe zdanie jednej z części tego artykułu wskazywało na pragnienie i świadomość jako punkty odniesienia w myśleniu o dekadentyzmie Żuławskiego. Tę część chciałbym zakończyć stwierdzeniem: rzeczone pragnienie i świadomość są z ducha Schopenhauera - ich odpowiednikami w myśli filozofa są żarłoczna wola oraz geniusz szczególnie narażony przecież na doznawanie cierpienia.

\section{Dlaczego koniec świata?}

Kilka stronic wcześniej padło pytanie o to, dlaczego Żuławski unicestwia świat w swoich wierszach. Pora zatem przyjrzeć się próbom przełamania dekadentyzmu i odnalezienia sensu.

Poeta poszukuje wytrwale, bada różne możliwe drogi wyjścia z beznadziejności, by je odrzucić, pokazawszy oczywiście najpierw ich nędzę, niewystarczalność, złudność. I tak oto padają kolejne bastiony sensu istnienia: aktywizm, Bóg, mądrość, hedonizm, asceza, miłość, a w końcu cierpienie jako wartość pozytywna i oczyszczająca. Świat odnajduje tu swój koniec wraz z upadkiem spójności metafizyki. Ale czy na pewno?

Wczesna twórczość poetycka Żuławskiego zasadniczo jest aktywistyczna, może nawet nietzscheańska, i nie zapowiada jeszcze rozczarowania, które towarzyszy utworom późniejszym. Tak też postrzegała ją Helena Karwackaa ${ }^{24}$ podkreślająca aktywizujący wydźwięk pierwszych trzech tomów autora: $\mathrm{Na}$ strunach duszy (1895), Stance o pieśni (1896) oraz Intermezzo (1897). Karwacka słusznie ograniczyła się do wczesnej twórczości poetyckiej Żuławskiego. Jednakże inaczej należy ocenić Wstęp Andrzeja Zdzisława Makowieckiego napisany do przygotowanego przez tego badacza wyboru wierszy Jerzego

${ }^{23}$ J. Żuławski, Galatea, [w:] tenże, dz. cyt., s. 108.

${ }^{24}$ Zob. H. Karwacka, Poeta modernistycznego przełomu, „Prace Polonistyczne” 1965 
Żuławskiego. Autor błędnie przypisuje aktywistyczny charakter całej poezji poety, pisząc:

Sens istnienia zostaje bowiem w poezji Żuławskiego uratowany. Zawiera się w heroicznym przyjęciu do wiadomości zła świata i ludzkiego cierpienia. Podmiot liryczny w twórczości autora Smutków wie, że wszystko, co człowieka otacza, nosi w sobie zapowiedź zła i cierpienia, godzi się niejako na immanentną ułomność duchową ludzi, usiłuje ją zrozumieć i z tego opanowywania rzeczywistości intelektem czerpie przeświadczenie o ludzkiej mocy, o znaczeniu poszukiwania wartości w świecie, który wartości zatracił. W samotności i heroicznej odwadze chce aktem poznania i zrozumienia tę rzeczywistość przezwyciężyćéc

W dalszej części Makowiecki podkreśla imperatyw aktywizmu intelektualnego i moralnego wynikający z owego intelektualnego przezwyciężenia rzeczywistości. Wskazuje on na protest poety przeciw stwarzaniu sobie dekadenckich usprawiedliwień dla bezsiły bezczynu. Stanowisko Makowieckiego musimy jednak uznać za nieporozumienie. O ile bowiem jego sąd o aktywistycznym punkcie dojścia poezji autora Trylogii księżycowej z pewną dozą nieufności możemy uznać w odniesieniu do wczesnej twórczości Żuławskiego, czyli tak jak to przedstawiła Karwacka, o tyle jednak poezja późniejsza o postawie aktywistycznej milczy. W miejsce cytowanych przez Makowieckiego słów podmiotu lirycznego „,bez ułudy i trzeźwo na bój pójdziem święty” z wiersza Naprzód! możemy śmiało zacytować inne, pochodzące z późniejszej twórczości poety:

Po cóż lotem bić w gwiazdy, na co życia wiry, na co piękność i szczęście i rozum i sława, i co z pieśni, co z dźwięku rozżalonej liry, po co szaleć i cierpieć, na co praca krwawa, na co myśli, co ssają krew, gdyby wampiry: jeśli końcem istnienia zgnilizna plugawa, jeśli śmierć nas przemieni w marną garstkę błota, jeśli wieczność - niestety - tylko bajka złota?26

Jest to ostatnia strofa wiersza o wymownym tytule $W$ prosektorium. Nie trzeba zresztą odwoływać się do poezji Żuławskiego, by pokazać nietrafność

\footnotetext{
25 A.Z. Makowiecki, Wstęp, [do:] J. Żuławski, Wiersze, Warszawa 1982, s. 14.

${ }^{26}$ J. Żuławski, W prosektorium, [w:] tenże, dz. cyt., s. 148.
} 
sądów Makowieckiego. Wskazuje on bowiem na pesymistyczny nastrój jako najsilniejszy akcent późniejszej twórczości, a w dalszej części powołuje się na cytowane już słowa pochodzące z wczesnych utworów, które mają świadczyć o postawie aktywistycznej. Problem w tym, że - jak już to zostało powiedziane - o postawie aktywistycznej w późnej poezji Żuławskiego nie ma mowy. Makowiecki dowodzi jedynie tego, co Karwacka, jednak popełnia błąd, dopatrując się postawy aktywistycznej w całej twórczości poetyckiej autora Stanc o pieśni.

Aktywizm bowiem - podobnie jak mądrość - nie mogą uchronić człowieka przed śmiercią, co wyraziście pokazuje wyżej przywołany wiersz. Kapituluje również koncepcja Boga, którego istota jest przecież niepoznawalna. Warto jednak dodać, że i tu Makowiecki nie ma racji, pisząc, iż według Żuławskiego Bóg nie istnieje. Podmiot liryczny tych utworów niejednokrotnie wyraża utratę wiary, zwątpienie, jednak nie jest to równoznaczne z przekonaniem o nieistnieniu Boga ${ }^{27}$. Agnostycyzm nie równa się ateizmowi.

Kapituluje także miłość, która przeradza się w odczucia mizoginistyczne, powszechnie znane twórcom młodopolskim. Stanowi ona zresztą jeszcze jedno źródło cierpień, dając jedynie krótkie chwile szczęścia.

Podobnie będzie z hedonizmem, który jest tu jałową i nieprzynoszącą szczęścia gonitwą za nieskończonością żarłocznej woli, oraz z modelem ascezy realizowanym przez tytułowego bohatera wiersza Święty Szymon Słupnik. Była zresztą już o tym mowa w częściach poświęconych Pascalowi i Schopenhauerowi.

I w końcu sens cierpienia nie znajduje tu żadnego potwierdzenia. Jedynym wyjściem z tego nieustannego negowania świata jest zatopienie się w ciszy, rezygnacja - życie spokojne i kontemplacyjne. Jedyny odnaleziony sens to postulat braku poszukiwania sensu, gdyż naraża to jednostkę na kolejne bolesne rozczarowania. Po tak długiej wędrówce zdaje się, że bohater liryczny wierszy Żuławskiego potwierdził jedynie banalną prawdę o nieuchronnej śmierci, której nie jest w stanie odsunąć ani mądrość, ani aktywizm. Świat jest tu światem pełnym sprzeczności, miejscem wrogim, nieustającym źródłem cierpienia. Biorący z nim rozbrat akt poety jest aktem unicestwienia.

7 Można by powiedzieć, że Makowiecki błędnie wprowadza tu relację sprzeczności, podczas gdy jest to tylko relacja antonimii. 